\title{
PENSION REFORMS AND PARTICIPATION IN SPAIN ${ }^{1}$
}

\begin{abstract}
The Spanish public pension system has periodically been reformed over the past three decades. These reforms have been of varying intensity and different in nature as regards their approval process. The first major reforms occurred in Spain in the 1980s and were characterised by their unilaterality due to the parliamentary majority of the government. They triggered a strong social response and various general strikes were called against their measures.

However, these reforms became more participatory by the mid-1990s. The main instrument of participation in pension reforms in the Spanish system is known as the Toledo Pact (Pacto de Toledo), which has been in force since 1995. It is a parliamentary commission that approves a series of declarative principles and recommendations to follow in the reform processes. Its purpose is to ensure broad political consensus before passing new regulations. Within this framework, another instrument used is social dialogue among government, unions and business organisations. Accordingly, there have been four agreements (1996, 2001, 2006 and 2011) approving a series of reform measures founded on the principles formulated in the Pact. On the basis of these agreements, the government in each case presented a bill to the Parliament for discussion and approval.

The last reform, which took place in 2013, was very significant due to a huge regression in terms of protection levels. Unlike prior reforms, it was passed without social dialogue and without following the consensus procedures of the Toledo Pact, thereby implying a return to unilaterality in this field.

The purpose of this paper is to analyse the functioning and consequences of these instruments of participation, focusing on explaining the Toledo Pact, how it works and how it has served to increase legitimacy and consensus in pension reforms as opposed to unilateral regulatory changes.

Słowa kluczowe: reforma emerytalna, partycypacja, demokracja, partnerzy społeczni

Key words: pension reforms, participation, democracy, social actors

1 This paper was presented at the Panel Pension Reform and Participation, in the $18^{\text {th }}$ ILERA World Congress held in Seoul on 23-27 July 2018. I would like to thank Pablo Arellano and Lilach Lurie for organising this panel and their comments. I am also grateful to all those who discussed and commented on the initial draft, specially Marius Olivier. The usual disclaimers apply. This paper is part of the research conducted within the Research Group in Labour and Social Security Law (greDTiSS), recognised as a Consolidated Research Group by the Agency for Management of University and Research Grants, dependent on the Catalan Government (2017 SGR 1563).
\end{abstract}




\section{Introduction}

Spanish society is concerned about and sensitive to its public social security system. ${ }^{2}$ There is social awareness of its importance as a social protection mechanism based on intergenerational solidarity that plays a decisive role in redistributing wealth to achieve equality. Consequently, although this field is a competence of the Parliament, political parties decided to exclude it from electoral debate and agreed on an instrument of participation aimed at increasing political and social consensus in designing and implementing its future reforms.

This 'consensual method of reforms ${ }^{3}$ was set up in 1995 and is known as the Toledo Pact (Pacto de Toledo). It is in fact a permanent commission of the Parliament that aims to ensure a greater level of consensus in this field before any regulatory changes are introduced. As will be seen later, a distinguishing feature of this instrument is its combination of political and socio-economic agreements. Consequently, the role of social actors has been very important. Social agreements reached by the government and most representative trade unions and employers' associations have been the basis for most of the major legal reforms undertaken over the past forty years, developing recommendations made within the framework of the Toledo Pact.

However, two unilateral reforms have also been carried out during this period, one before and another after the Toledo Pact. They share several common features, such as a negative economic context and the existence of a government with a parliamentary majority. Their main differences are the existence of this socio-political agreement, which was breached by the government, and the austerity policies and implementation of recommendations (and pressures) received from international actors. In this sense, the EU exercised a significant influence on domestic reform and the participation of social actors was ignored.

2 The Spanish Constitution recognises the right to social security in Article 41, addressing a mandate for public authorities to maintain a public social security system to guarantee adequate social assistance and benefits in situations of hardship for all citizens. On the principles of the constitutional model of social security, see M.R. Alarcón Caracuel, La Seguridad Social en España, Pamplona 1999, passim.

It includes two levels of protection: a pay-as-you-go pension scheme, based on defined benefits, and a non-contributory or universal pension scheme. More information on the main features of the Spanish pension system can be consulted at OECD, Pensions at a Glance 2017. How does Spain compare?, 2017, 1-2, www.oecd.org/spain/PAG2017-ESP. For a deeper analysis of the basis and principles of the non-contributory schemes, see J. Fargas Fernàndez, Análisis crítico del sistema español de pensiones no contributivas, Pamplona 2002.

It also declares the possibility of supplemental protection and benefits that are optional in nature, although this mechanism plays a fairly insignificant role (according to OECD, pension funds represented 9.5\% of the GDP in 2017).

3 J.L. Tortuero Plaza, O. del Aguila Cazorla, E. Martín Jiménez, F. Moreno Romero, La reforma de la jubilacion: Políticas de pensiones y políticas de empleo, Premios FIPROS - Fondo para el Fomento de la Investigación de la Protección Social 2010, http://www.seg-social.es/prdi00/groups/public/documents/ binario/143941.pdf (accessed: 1.10.2018). 
This paper attempts to offer a diachronic analysis of pension reform and participation in Spain, focusing mainly on explaining the Toledo Pact, how it works and how it has increased legitimacy and consensus in pension reforms as opposed to those exceptional cases in which unilateral regulatory changes were made.

\section{Unilateral reforms in the 1980s}

Act 26/1985, of 31 July, on urgent measures to rationalise the structure and protective action of Social Security, was the first major reform after the restoration of democracy. It was adopted unilaterally by the first socialist government of Felipe González, which took advantage of its parliamentary majority.

The main purpose of the reform was to reduce expenditure in pensions, which may be viewed as a structural aim over the past four decades in many countries with developed PAYG public pension systems. During the period 1980-1985, the number of pensioners increased by one million people (from 4.4 to 5.4 million) and expenditure increased from $5.77 \%$ to $7.52 \%$ of GDP. Two of these different changes can be highlighted. The reform tightened conditions to pension entitlement, with the qualifying period for a retirement pension increasing from 10 to 15 years. In addition, the calculation formula of the benefit was also modified, resulting in a final amount that was usually lower. Before the reform, the amount was the result of the average of contributions made over the two previous years before retirement, but the calculation period increased to eight years after this Act.

This regulation was highly controversial and generated strong social contestation. The Trade Union Confederation of Workers' Commissions (CCOO) called for a general strike on 20 June 1985. Although the General Workers' Confederation (UGT), the other most representative national trade union, did not participate, ${ }^{4}$ the strike was supported by other unions such as USO, CNT, ELA-STV and INTG. Over the following decade, until the beginning of the participatory stage, social confrontation was evident in the call for three more general strikes against the Socialists (1988, 1992 and 1994).

\section{The Toledo Pact as a type of State Agreement: guidelines to reforming the social security system}

According to G. Rodríguez Cabrero ${ }^{5}$, social tensions 'convinced the socialist government' of the need for political parties to negotiate a pact, which is the reason why pension

4 The traditional tight bonds between left-wing political parties and trade unions should be noted, which were gradually broken in the following years. In that time, the links between the Socialist Party (PSOE) and the trade union UGT were still quite strong, although this reform and other decisions caused the rupture.

5 G. Rodríguez Cabrero, The reform of the public pension system in Spain, Institute of Public Goods and Policies (CSIC-IPP) Working Papers No. 02-13a, 2002, http://ipp.csic.es/sites/default/files/content/ workpaper/2002/dt-0213a.pdf (accessed: 1.10.2018). 
reforms became more participatory by the mid-1990s. The main instrument used, as already mentioned, is colloquially known as the Toledo Pact, after the city in which it was formally signed. It is in fact a parliamentary commission that analyses the situation of the social security system and approves a series of declarative principles and recommendations guiding future reform processes. Its purpose is to ensure broad political consensus before passing new regulations.

Its origins can be found within a Parliamentary Committee on Budgetary Affairs in which a working group to analyse Social Security was set up by a non-legislative motion that was initiated by the Catalan parliamentary group Convergència $i$ Unió. This working group adopted a text entitled 'Analysis of the structural problems of the social security system and the main reforms that must be undertaken'. It included fifteen recommendations in this field and was passed by the Committee on Budgetary Affairs on 30 March 1995, to be later ratified in a plenary session by the Parliament.

The guidelines for future reforms decided upon in the document were:

1. Separating and clarifying funding sources in order to finance contributory pensions only through social contributions and non-contributory and universal contributions only through general taxes.

2. Constitution of reserves: creation of a fund with surpluses of positive economic cycles to deal with negative cycles.

3. Improving contribution bases to match them with real wages and creating a single contribution ceiling.

4. Financing special schemes based on the principle of similar contribution for similar protection.

5. Improving collection mechanisms to reduce late payments and the black economy.

6. Simplifying and integrating special schemes, gradually reducing these through integration into the general scheme or the special scheme for self-employed persons.

7. Integrating social security management by improving and incorporating different areas, such as membership, collection and benefits.

8. Evolution of contributions, reducing these to boost employment, provided that this is allowed by the financial equilibrium of the system, and prioritising low-skilled workers.

9. Equity and contributivity of the system, in the sense of achieving greater proportionality between benefits and the previously undertaken contributory efforts.

10. Introducing a flexible, gradual, progressive system in terms of retirement age, including incentives to remain active beyond the statutory retirement age (65) by reducing or eliminating contributions for these workers.

11. Maintaining the purchasing power of pensions by automatically revaluing them according to changes in the consumer price index.

12. Strengthening the principle of solidarity when possible, for instance improving the amount of widows' pensions or increasing the period in which orphans' benefits can be enjoyed. 
13. Improving management, specifically in relation to monitoring sickness and invalidity benefits to reduce possible fraud, among other measures.

14. Enhancing complementary social protection by improving fiscal stimulus measures.

15. Analysing and monitoring the evolution of the system every five years by creating a working group to examine the present and future of the system.

According to this last recommendation, '(...) (c)urrent forecasts can be significantly altered in the coming decades. It is therefore of the greatest interest that instruments are used, in the Government and in the Parliament, to monitor and periodically evaluate the evolution of the magnitudes that intervene in the financial equilibrium of the system to operate with the interventions that were required in any eventuality. This information will be transferred to social partners (...)'. This has two different consequences: on the one hand, the possible renewal of the guidelines after monitoring; on the other hand, the reference to social partners has been used to include them in the transformation process of these recommendations into specific legal contents, as previously noted.

In application of the last recommendation on the periodic evaluation of the system, it was renewed through Resolution 2 October 2003 with the addition of five new guidelines:

1. New working methods: paying special attention to part-time and temporary work and the possibility of making benefits and salaries compatible should be analysed.

2. Women and social protection: along the lines of advancing in policies reconciling family and professional life and eliminating the gender wage gap.

3. Dependency: it is considered that a system to address this problem should be created. ${ }^{6}$

4. Disability: the impact of public policies on this group should be analysed.

5. Immigration: establishing measures to guarantee the incorporation of migrants into the labour market and social protection system.

The working group approved a report on the Evaluation and Reform of the Toledo Pact on 29 December 2010 and this was later passed by a plenary parliamentary session on 25 January 2011. One of its main measures concerned increasing the statutory retirement age. The main idea was to increase the effective retirement age to guarantee the future viability of the pension system, considering the increase in life expectancy, reduction of working-age population and increase in pensioners. To this end, it was pointed out that 'any change in the legal age of retirement must be progressive without affecting those who are going to retire in the immediate future and should not be carried out in a homogeneous and forced manner for all people.' It is important to emphasise the dissenting opinion unanimously passed by all parliamentary groups on the role of the working group in charge of monitoring and evaluating the social security system: it 'defends the maintenance and improvement of the public pension system, based on a PAYG scheme and solidarity'.

6 Some years later, a new social protection system was created by Act 39/2006, of 14 December, on the promotion of personal autonomy and care of dependent persons. 
After the most recent authoritarian, unilateral period in which a controversial regulation was passed, as will be seen later, the working group is currently holding various meetings. ${ }^{7}$ Indeed, among the different issues subject to discussion, the new revaluation index that was unilaterally introduced by the former government in 2013 can be highlighted, in line with agreeing to a system that maintains the purchasing power of pensioners.

\section{The Toledo Pact as a model of participation in pension reform}

Three major phases can be identified when it comes to general procedure. First, the working group includes the participation of all parliamentary groups. An important basis of its activity is a series of public hearings in which various individuals appear to give their opinions and these people are viewed as working group deputies. They include representatives of trade unions, employers' associations, public institutions, specialists and anyone who believes they can contribute useful elements in the debate to reach some conclusions. Second, after the recommendations are approved in the Parliament, a participatory process involving social partners commences. During this, the government and social partners agree on specific measures based on the guidelines. After this, in the final stage, the government drafts a bill based on this agreement, following the usual procedure in the Parliament and Senate. The executive branch guides the entire process and legislative power defines the guidelines and the specific contents of the regulation both at the beginning and end.

As mentioned earlier, there is a reference to social partners in the first set of guidelines offered by the Toledo Pact. Legislative power has considered the constitutional provision that recognises the important position of employers' associations and trade unions (Article 7) ${ }^{8}$ in the political, social and economic arena -within the 'social and

7 Discussions that took place within the working group are analysed in the chronicles of D. Gutiérrez Colominas, Comisión de seguimiento y evaluación de los acuerdos Pacto de Toledo (Sesión 25), Nueva Revista Española de Derecho Del Trabajo 2018, 209, p. 295-316; F.J. Hierro Hierro, Comisión de seguimiento y evaluación de los Acuerdos Pacto de Toledo (Sesiones 1 a 5), Nueva Revista Española de Derecho Del Trabajo 2017, 195, p. 305-316; F.J. Hierro Hierro, Comisión de seguimiento y evaluación de los Acuerdos Pacto de Toledo (Sesiones 11 a 15), Nueva Revista Española de Derecho Del Trabajo 2017, 198, p. 375386; F.J. Hierro Hierro, Comisión de seguimiento y evaluación de los Acuerdos Pacto de Toledo (Sesiones 16 a 20), Nueva Revista Española de Derecho Del Trabajo 2017, 199, p. 307-327; F.J. Hierro Hierro, Comisión de seguimiento y evaluación de los Acuerdos Pacto de Toledo (Sesiones 21 a 24), Nueva Revista Española de Derecho Del Trabajo 2017, 202, p. 313-326; F.J. Hierro Hierro, Comisión de seguimiento y evaluación de los Acuerdos Pacto de Toledo (Sesiones 6 a 10), Nueva Revista Española de Derecho Del Trabajo 2017, 196, p. 269-281..

8 'Article 7. Trade unions and employers' associations contribute to the defence and promotion of the economic and social interests which they represent. Their creation and the exercise of their activities shall be unrestricted in so far as they respect the Constitution and the law. Their internal structure and operation must be democratic.' 
democratic State, subject to the rule of law', under Article 1- alongside that of political parties (Article 6). ${ }^{9}$ According to the Constitutional Court, this recognition means that 'trade unions are a basic component or an essential institution of the Spanish constitutional system' (Constitutional Court ruling 101/1996). After a 40-year period of dictatorship, Spain's Constitution defines a democratic model of industrial relations, assuming a principle of political and social pluralism. An expression of this, in the field of social security, can be found in Article 129.1 of this Constitution, which states that ' $(t)$ he law shall establish the forms of participation in Social Security and in the activities of those public bodies whose operation directly affects the quality of life or the general welfare'.

\section{An overview of agreed reforms}

Within this framework, social dialogue among the government, trade unions and employers' organisations establishes specific measures that consider these recommendations. There have been four agreements (1996, 2001, 2006 and 2011) approving a series of reform measures founded on the principles formulated in the Toledo Pact. ${ }^{10}$ On the basis of these agreements, the government presented a bill to Parliament for discussion and approval (see the Table in the Appendix, in which an overview of various renewals of the Toledo Pact, Social Agreement and subsequent Acts can be seen).

There were two reforms following the process explained earlier after the first set of recommendations by the Parliament within the framework of the Toledo Pact. The first began in 1996 with an Agreement on consolidating and rationalising the social security system, signed on 9 October. It was subscribed by the Popular Party (PP) government and the trade unions $\mathrm{CCOO}$ and UGT. This first agreement was reached within a context of economic crisis and was not signed by the employers' associations.

Despite strong pressure in favour of a public system of capitalisation, an important basic agreement was the idea of reinforcing the PAYG system and the principle of intergenerational solidarity upon which it is based. Its contents contained various measures to improve protection, such as an increase in widowers' pensions. On the other hand, the calculation period of the retirement pension increased from eight to fifteen years. It was a very similar measure to the one unilaterally adopted in 1985; however, it was not controversial at that time. According to Tortuero Plaza et al., it is indicative of the

9 'Article 6. Political parties are the expression of political pluralism; they contribute to the formation and expression of the will of the people and are a fundamental instrument for political participation. Their creation and the exercise of their activities are free in so far as they respect the Constitution and the law. Their internal structure and operation must be democratic.'

10 For a more detailed, descriptive analysis of the contents of the original Toledo Pact and its subsequent versions, Social Agreements and later norms implementing them, see J.A Panizo Robles, Dos décadas de reformas de la Seguridad Social: Del Pacto de Toledo de 1995 al Acuerdo Social y Económico de 2011, Revista de Trabajo y Seguridad Social 2011. 
effectiveness of the agreed method of the Toledo Pact because it offers legitimacy and enables it to be accepted

Then, Act 24/1997, of 15 July, on the consolidation and rationalisation of the social security system. This introduced changes in determining retirement pension amounts in order to allow greater proportionality between the years of contributions and the percentage to be applied in the calculation basis. The requirements to access early retirement were modified, reserved only to those that were mutualist on 1 January 1967, when the current social security system began, establishing coefficients that reduced the amount considering the time remaining for the ordinary age and the time contributing to the system. Incentives to extend working life were also introduced.

A new social agreement was reached only five years later: the Agreement to improve and develop the social protection system was signed on 9 April 2001. It was subscribed by the government of the Popular Party, the trade union CCOO (the other most representative trade union, UGT, did not ultimately sign the agreement, although it participated throughout the entire bargaining process) and the two major national employers' associations: CEOE (Confederación Española de Organizaciones Empresariales) and CEPIME (Confederación Española de la Pequeña y Mediana Empresa), signing it for the first time.

The economic context and financial situation of the system was more positive, thereby motivating the creation of a reserve fund by taking advantage of system surpluses, as suggested in the Pact's recommendation. Within this context, the separation of funding sources occurs, a measure that later became controversial when periods of high unemployment placed the financial viability of the system under strain. On the other hand, the permanence of the active worker was voluntarily encouraged through incentives and bonuses.

Then, Act 35/2002, of 12 July, on establishing measures for a gradual, flexible retirement system, was passed. The introduction of this new flexible retirement mechanism allowed several possibilities: early retirement before the ordinary age, with high contribution periods and a reduction in the benefit amount; deferred retirement after 65, including various measures to incentivise this, and partial retirement, viewed as an employment mechanism to rejuvenate companies' workforces.

A new social agreement in 2006 followed the renewal of the Toledo Pact in 2003. This Agreement on social security measures signed on 2 June has a peculiarity that is worth underlining. It is the first time that all the actors ideally involved in the bargaining process signed if for the first time: the government (in this case, the Socialist Party, PSOE), most representative national trade unions (CCOO and UGT) and employers' organisations (CEOE and CEPIME). The economy was experiencing a period of growth and so the renewal of the Pact, as noted earlier, included new phenomena to consider, such as women and migrants or dependency. However, the agreement insisted on reinforcing contributions to guarantee the financial equilibrium of the system.

As a consequence, Act 40/2007, of 4 December, on measures within the field of social security, was passed. One of its most important features was that the theoretical days 
of contribution were not considered when computing the qualifying period of 15 years to obtain a retirement pension. Thus, 15 real years of contribution (5,475 days) were required instead of the 12.86 real years needed until that moment. ${ }^{11}$ Reduction coefficients in early retirement and bonus coefficients in deferred retirement were improved and requirements for access to partial retirement were also reformed.

The last agreed reform was in 2011, which was approved almost simultaneously with the Toledo Pact working group report. After the Social and economic agreement for growth, employment and pension guarantee signed on 2 February 2011, Act 27/2011, of 1 August, on the adaptation and modernisation of the Social Security system, was passed. The most important changes it introduced were aimed at making the system financially sustainable: the statutory retirement age was increased from 65 to 67, the period of contribution to obtain a full pension was increased from 35 to 37 years and the calculation period was also increased from the last 15 years of salary to the last 25 years. ${ }^{12}$

\section{The latest unilateral (and regressive) reforms: The impact of economic purposes and international organisations}

The latest reforms were very significant not only from the point of view of content, due to the huge regression of levels of protection they caused, but also from a formal perspective, as it meant a return to unilaterality in this field, without the consensus procedures of the Toledo Pact. The government led this reform without any prior political or social agreement.

This could be viewed as part of a new wave of reforms in which one distinctive feature is perhaps the special impact of certain global economic and/or political actors in domestic legal systems. ${ }^{13}$ Act 23/2013, of 23 December, regulating the sustainability factor and the revaluation index of social security pensions, was passed within a context

11 These theoretical days of contribution are in fact a legal fiction. It refers to the two annual extra payments, usually taking place in summer and Christmas. As long as workers receive fourteen monthly payments and contribute to the social security system on that basis each year, it is considered that each year has theoretically fourteen months to the purposes of fulfilling the requirement of a qualifying period. In consequence, each day is equivalent to 1.16666 theoretical days of contribution (14/12).

12 The problems of age discrimination that this reform, and the following one in 2013, creates have been noted, due to an 'increase of the contributory level for social security, and a decrease in the level of protection - especially in the case of women' (J. López López, C. Chacartegui, Age Discrimination: A vision from the South, in: A. Numhauser-Henning, M. Ronnmar (eds.), Age Discrimination and Labour Law: Comparative and Conceptual Perspectives in the EU and Beyond (pp. 263-278), Alphen aan den Rijn (The Netherlands) 2015, passim).

13 Although an analysis of pension reform policy from the 1990s shows that the domestic discourse in reforms has been aligned with EU institutions since that time, due to the need to comply with requirements no join the European Monetary Union (L.N.Carrera, When does Europe matter? An analysis of pension reform policy in Spain and Italy, European Union Studies Association (EUSA) $11^{\text {th }}$ Biennial International Conference 2009, p. 1-32, http://eprints.lse.ac.uk/24602/(accessed: 1.10.2018). 
of harsh austerity measures and a soft bailout for Spain. Actors such as the OECD, World Bank, IMF (through their reports and recommendations) and the EU (through its economic governance) had a clear influence in the orientation and specific content of these reforms. ${ }^{14}$

According to some scholars, the introduction of the sustainability factor was in fact a 'quiet shift' of the public pension system, which thereby became a defined contribution scheme. ${ }^{15}$ On the other hand, a new revaluation index was also introduced that took into consideration different variables (interannual variation of incomes, contributory pensions and system expenditure).

Although there was no strong reaction against this social security reforms in general, the specific employment reform that was introduced in 2012 led to the calling of two general strikes against its measures (on 29 March 2012 and 14 November 2012). However, an interesting grassroots movement has emerged against these measures, especially the new revaluation index. This movement has been led by pensioners who have become self-organised in local groups and coordinated regionally and nationally under the name of the Pensioner Tide (Marea Pensionista). ${ }^{16}$ They have combined different actions against these measures, such as informative activities about the consequences of the reform and demonstrations. But a very interesting question that should be underlined is the judicialization they have undertaken.

In fact, there is a previous normative example of unilaterality in the regulatory changes of pensions: Decree-Law No. 28/2012, on measures of consolidation and guarantee of the social security system. For the first time, it established the non-revaluation of pensions by automatically taking into account the CPI and set a lower percentage. Domiciano Sandoval, a pensioner and activist of Marea Pensionista in Barcelona, and Miguel Arenas, lawyer at Col-lectiu Ronda, a lawyers' cooperative, have appealed against these measures in Spanish Labour Courts and the European Court of Human Rights, which has accepted it for processing. ${ }^{17}$ Consequently, and also because of other political circumstances, a special increase in pensions was recently passed and the revaluation index is under discussion within the working group.

14 J.A. Fernández Avilés focuses on the tensions between economic and social purposes see J.A. Fernández Avilés, Nuevas recomendaciones sociolaborales Europeas para la reforma: más tensión entre la lógica economicista y las razones sociales, Revista de Trabajo y Seguridad Social 2018, 424, p. 5-12.

15 J. Díaz-Giménez, Las Pensiones Europeas y sus Reformas Recientes, Instituto BBVA de Pensiones No. Documento de trabajo 7, 2014; J.L. Monereo, J.A. Fernández Bernat, El factor de sostenibilidad en España: ¿Un nuevo paso para el cambio silencioso de modelo de pensiones públicas? Revista de Derecho Social 2013, 62, p. 209-238.

16 Information on their activities can be seen at http://mareapensionista.org (last accessed: 20.07.2018).

17 More information can be retrieved from https://www.cronda.coop/es/Actualidad/Noticias/ Admitida-a-tramite (last accessed: 20.07.2018). 


\section{Some conclusions for discussion}

According to Schludi (2005), concertation is a 'condition for successful implementation of pension reforms', regardless of whether it occurs between the government and other political parties, between the government and trade unions or, ultimately, among all these actors. Consequently, the Spanish experience seems to be useful in terms of legitimacy and acceptance, at least from a formal point of view, regardless of the results of reforms that may be more or less satisfactory for citizens.

However, two points should be noted. First, this mechanism depends on political will. Thus, the confluence of absolute majorities, on the one hand, and economic crises and serious financial imbalances in the system, on the other hand, have historically led to the unilateral imposition of reforms. This was especially concerning in the 2013 reform, after the Toledo Pact, to the extent that global actors seemed to replace national democratic instruments of participation, both in a political and socio-economic field.

And second, although an interesting instrument of participation, using the legal instruments recognising collective rights and giving some competences to most representative national trade unions, some imperfections exist to the extent that the positions of other trade unions (some of them the most representative in an Autonomous Community) and civil society and citizens associations, such as the Pensioners Tide, are not considered. ${ }^{18} \mathrm{~A}$ good example of this is the general strike called on 27 January 2011 by the trade unions ELA-STV, LAB, CIG, CGT and CNT in some Autonomous Communities (Catalonia, Galicia, Euskadi and Navarra) and the general demonstrations that took place in various cities at a national level against the 2011 pension reform. Although the Toledo Pact mechanism maximises consensus, it does not guarantee full agreement on either the guidelines or measures. The extension of the participatory process should be considered in order to let other voices contribute to co-construct reforms and a system of higher majorities should be implemented to maximize consensus as much as possible.

As Duchemin and Weber (2013) has indicated, the financial crisis led to a lower degree of influence by social partners on pension reforms; in fact, they stress that social partners had more opportunity to bargain in those cases without budget constraints. ${ }^{19}$ A very good example can be found in the resurgence of unilateral (and very deep and regressive) changes in 2013, under the Popular Party government, which had an absolute majority in the Parliament.

18 According to OECD data, trade union membership was 13.9\% in Spain, in 2015.

19 They indicate four different cases in their report on recent reforms of statutory PAYG pension systems: unilateral reforms (Greece, Portugal, etc.); reforms with prior consultation of social partners, but without influencing the final result due to strong disagreements in some aspects (Belgium, France, Italy); reforms with prior bargaining with trade unions, which obtained several outcomes in the final regulations, accepting the increase of the statutory retirement age (Netherlands, Spain); and, finally, those cases, such as Norway, with a strong social dialogue, where social partners had an important influence in reforms. This report, however, was published before the Spanish reform of 2013, so the classification in that group is due to the previous reform of 2011. 
A last, but not least, reflection has to do with the classical tensions between economic interests and the efficacy of social rights. Despite this degree of participation, it has been noted that the Toledo Pact, and its later implementation, was initially structured upon a main principle of a financial nature instead of a prior reason of protection, thereby conditioning this protection to financing. ${ }^{20}$

\section{Appendix}

Table 1. Social Security Reforms (1985-2018)

\begin{tabular}{|c|c|c|c|}
\hline \multirow{2}{*}{ Unilateral reforms } & $\begin{array}{l}1985 \text { (socialist } \\
\text { government of Felipe } \\
\text { González) }\end{array}$ & \multicolumn{2}{|c|}{$\begin{array}{l}\text { Act } 26 / 1985 \text {, of } 31 \text { July, on urgent measures to } \\
\text { rationalise the structure and protective action of } \\
\text { social security }\end{array}$} \\
\hline & $\begin{array}{l}2013 \text { (Popular Party } \\
\text { government of Mariano } \\
\text { Rajoy) }\end{array}$ & \multicolumn{2}{|c|}{$\begin{array}{l}\text { Act } 23 / 2013 \text {, of } 23 \text { December, regulating the } \\
\text { sustainability factor and the revaluation index of } \\
\text { social security pensions }\end{array}$} \\
\hline \multirow{4}{*}{ Agreed reforms } & \multirow[t]{2}{*}{ Toledo Pact (1995) } & $\begin{array}{l}\text { Agreement on } \\
\text { consolidation and } \\
\text { rationalisation of the } \\
\text { social security system (9 } \\
\text { October 1996) }\end{array}$ & $\begin{array}{l}\text { Act } 24 / 1997, \text { of } 15 \text { July, } \\
\text { on consolidation and } \\
\text { rationalisation of the } \\
\text { social security system }\end{array}$ \\
\hline & & $\begin{array}{l}\text { Agreement for the } \\
\text { improvement and } \\
\text { development of social } \\
\text { protection system } \\
\text { (9 April 2001) }\end{array}$ & $\begin{array}{l}\text { Act } 35 / 2002 \text {, of } 12 \text { July, } \\
\text { establishing measures } \\
\text { for a gradual and flexible } \\
\text { retirement system }\end{array}$ \\
\hline & $\begin{array}{l}\text { Renewal of Toledo Pact } \\
\text { (2003) }\end{array}$ & $\begin{array}{l}\text { Agreement on social } \\
\text { security measures } \\
\text { ( } 2 \text { June 2006) }\end{array}$ & $\begin{array}{l}\text { Act } 40 / 2007 \text {, of } 4 \\
\text { December, on measures } \\
\text { within the field of social } \\
\text { security }\end{array}$ \\
\hline & $\begin{array}{l}\text { Follow-up of Toledo Pact } \\
\text { (2003-2008) } \\
\text { Report of Toledo Pact } \\
\text { (2011) }\end{array}$ & $\begin{array}{l}\text { Social and economic } \\
\text { agreement for growth, } \\
\text { employment and } \\
\text { pension guarantee ( } 2 \\
\text { February 2011) }\end{array}$ & $\begin{array}{l}\text { Act } 27 / 2011 \text {, } \\
\text { of } 1 \text { August, on the } \\
\text { adaptation and } \\
\text { modernisation of the } \\
\text { social security system }\end{array}$ \\
\hline
\end{tabular}

Source: Own work.

20 In this sense, S. González Ortega criticises the separation of funding sources, warning about future risks, such as recent problems to pay benefits with contributions (see S. González Ortega, La reforma de las pensiones públicas a través de la definición de sus principios organizativos, Cuadernos de Relaciones Laborales 1998, 12, p. 35-53. 


\section{References}

Alarcón Caracuel M.R., La Seguridad Social en España, Pamplona 1999.

Carrera L.N., When does Europe matter? An analysis of pension reform policy in Spain and Italy, European Union Studies Association (EUSA) $11^{\text {th }}$ Biennial International Conference 2009, p. 1-32, http://eprints.lse.ac.uk/24602/ (accessed: 1.10.2018).

Díaz-Giménez J., Las Pensiones Europeas y sus Reformas Recientes, Instituto BBVA de Pensiones No. Documento de trabajo 7, 2014.

Duchemin C., Weber T., Social partners' involvement in pension reform in the EU, European Observatory of Working Life - Eurofound, https://www.eurofound.europa.eu/ef/sites/ default/files/ef_files/pubdocs/2013/691/en/1/EF13691EN.pdf (accessed: 1.10.2018).

Fargas Fernàndez J., Análisis crítico del sistema español de pensiones no contributivas, Pamplona 2002.

Fernández Avilés J.A., Nuevas recomendaciones sociolaborales Europeas para la reforma: más tensión entre la lógica economicista y las razones sociales. Revista de Trabajo y Seguridad Social 2018, 424.

González Ortega S., La reforma de las pensiones públicas a través de la definición de sus principios organizativos, Cuadernos de Relaciones Laborales 1998, 12.

Gutiérrez Colominas D., Comisión de seguimiento y evaluación de los acuerdos Pacto de Toledo (Sesión 25), Nueva Revista Española de Derecho Del Trabajo 2018, 209.

Hierro Hierro F.J., Comisión de seguimiento y evaluación de los Acuerdos Pacto de Toledo (Sesiones 1 a 5), Nueva Revista Española de Derecho Del Trabajo 2017, 195.

Hierro Hierro F.J., Comisión de seguimiento y evaluación de los Acuerdos Pacto de Toledo (Sesiones 11 a 15), Nueva Revista Española de Derecho Del Trabajo 2017, 198.

Hierro Hierro F.J., Comisión de seguimiento y evaluación de los Acuerdos Pacto de Toledo (Sesiones 16 a 20), Nueva Revista Española de Derecho Del Trabajo 2017, 199.

Hierro Hierro F.J., Comisión de seguimiento y evaluación de los Acuerdos Pacto de Toledo (Sesiones 21 a 24), Nueva Revista Española de Derecho Del Trabajo 2017, 202.

Hierro Hierro F.J., Comisión de seguimiento y evaluación de los Acuerdos Pacto de Toledo (Sesiones 6 a 10), Nueva Revista Española de Derecho Del Trabajo 2017, 196.

López López J., Chacartegui C., Age Discrimination: A vision from the South, in: A. Numhauser-Henning, M. Ronnmar (eds.), Age Discrimination and Labour Law: Comparative and Conceptual Perspectives in the EU and Beyond (pp. 263-278), Alphen aan den Rijn (The Netherlands) 2015.

Monereo J.L., Fernández Bernat J.A., El factor de sostenibilidad en España: ¿Un nuevo paso para el cambio silencioso de modelo de pensiones públicas? Revista de Derecho Social 2013, 62.

OECD, Pensions at a Glance 2017. How does Spain compare?, 2017, 1-2, www.oecd.org/spain/ PAG2017-ESP.

Panizo Robles J.A., Dos décadas de reformas de la Seguridad Social: Del Pacto de Toledo de 1995 al Acuerdo Social y Económico de 2011, Revista de Trabajo y Seguridad Social 2011. 
Rodríguez Cabrero G., The reform of the public pension system in Spain, Institute of Public Goods and Policies (CSIC-IPP) Working Papers No. 02-13a 2002, http://ipp.csic.es/sites/ default/files/content/workpaper/2002/dt-0213a.pdf (accessed: 1.10.2018).

Schludi M., The Reform of Bismarckian Pension Systems, Amsterdam 2005.

Tortuero Plaza J.L., del Aguila Cazorla O., Martín Jiménez E., Moreno Romero F., La reforma de la jubilacion: Políticas de pensiones y políticas de empleo, Premios FIPROS - Fondo para el Fomento de la Investigación de la Protección Social, 2010, http://www.seg-social.es/ prdi00/groups/public/documents/binario/143941.pdf (accessed: 1.10.2018). 